\title{
Ecological Connectivity Index Mapping for Green Infrastructure Development in Kaduna State, Northern Nigeria
}

\author{
Fanan $\mathrm{UJOH}^{1}$, Patrick Samson Udama ENECHE ${ }^{2}$ \& Micah Ekwutosi OBIEGBU ${ }^{3}$ \\ ${ }^{1}$ Urban Base Consulting, Abuja, Nigeria \\ ${ }^{2}$ Department of Geography \& Environmental Studies, Kogi State University, Anyigba, Nigeria \\ ${ }^{3}$ Department of Building, Abia State University, Uturu, Nigeria \\ Correspondence: Patrick Samson Udama ENECHE, Department of Geography \& Environmental Studies, Kogi \\ State University, Anyigba, Nigeria. E-mail: Enelche.psu@ksu.edu.ng
}

Received: December 23, 2018

Accepted: January 22, 2018

Online Published: May 14, 2018

doi:10.5539/enrr.v8n2p116

URL: https://doi.org/10.5539/enrr.v8n2p116

\begin{abstract}
Infrastructural development is considered one of the key steps towards economic advancement and prosperity, although the ecological basis of such intent is often not enshrined in the policies of governments, especially in most developing nations. Thus, infrastructural development has further increased fragmentation of ecologically-rich landscapes, causing biodiversity losses, reduced specie richness and diversity and climate change. Hence, the need for green infrastructure development. This study made use of Geographic Information System (GIS) tool to explore areas with high Ecological Connectivity Index (ECI) that could (easily) support green infrastructure development in Kaduna State in the face of climate change impacts which is already ravaging the region. Kaduna State land use/cover map and Aster GDTM elevation data were acquired, processed and analyzed using ArcGIS 10.5 software. A spatial model was developed that made use of the combination of elevation, slope and land use/cover data of the State via Multi-Criteria Evaluation (MCE) to reveal potentially viable and ecologically-rich areas of the State and the most efficient links between such areas. A total distance of 878 kilometers of potential ecological corridors in the study area were mapped and therefore, serve as a base to be considered in embarking on a state-wide green wall infrastructure development program by Kaduna State government. It is however recommended that Kaduna State as well as other state governments, particularly in northern Nigeria, ought to roll-out phased green infrastructure investment program(s), adopt the use of shrubs and trees in building green walls and to localize all the gains of the continental-wide Green Wall initiative as this will further reduce the threats of climate change in the region. The study also recommended the inclusion of other landscape variables/descriptors (e.g. road proximity, soil properties, cultural setting of local communities, etc.) into building a more comprehensive model to strengthen the accuracy of the map and the model presented in this study.
\end{abstract}

Keywords: Ecological connectivity index, green infrastructure, built infrastructure, least-cost path, Great Green Wall

\section{Introduction}

Infrastructure development is considered one of the key steps toward economic advancement, especially among developing nations seeking to transform their economies from import-dependent to self-reliance. Although economically invaluable, there are ecological problems arising from habitat fragmentation and biodiversity loss due to infrastructural developments of different scales (Collinge, 1996; Mallarach \& Marull, 2006; Chang et al., 2012; Yigitcanlar \& Lee, 2014; Yigitcanlar \& Dizdaroglu, 2015, Onwuka et al., 2017; Musa et al., 2017). This include warming air and land surface temperatures, changing precipitation regimes, etc. and these again have been projected to exacerbate other natural hazards such as desertification, drought, exposure to infectious and hyperthermia diseases, compromise food and water security, amongst many (World Bank, 2010; IPCC, 2014; Ifatimehin et al., 2016). Given the scale of direct/indirect and short/long term impacts on the physical environment due to infrastructural development in cities and across regions, there is urgent need for effective and resilient development planning by relevant authorities to combat this scenario. 
The Nigerian Government's Vision 20:20:20 aim is to promote sustained and inclusive economic growth and elevate the nation's economy to be among the top 20 economies in the world by year 2020 (African Development Bank, 2014). Such is often perceived to be achieved mainly through the availability of appropriate economic and social infrastructure, hence the prioritization of improved quality of infrastructure services with little consideration to their ecological footprints. In fact, Nigeria's Federal and State governments are currently making concerted efforts to improve the current poor state of infrastructure in order to meet the demand of the growing population as contained in the National Infrastructure Master Plan (National Planning Commission, 2015) and other sectoral infrastructure framework plans such as the World Bank Group's (2015) "Highways to Success or Byways to Waste: Estimating the Economic Benefits of Roads in Africa", and "An Infrastructure Action Plan for Nigeria: Closing the Infrastructure Gap and Accelerating Economic Transformation" by the African Development Bank (2014).

Kaduna State Government in Northern Nigeria is currently expanding (and planning to further expand) its infrastructure (rural roads, highways, rail, solid waste management plants, agricultural productivity, airport, water, energy, etc.) across the State. Given that the state is located in northern Nigeria, an ecologically fragile part of the nation (where climate change impacts, particularly desertification and drought are fast encroaching), there is absolute need to incorporate an ecological modelling framework. This will no doubt inject smart development and conservation planning in the process of infrastructure deployment in the state. The goal ought to be as to instill a systematical, responsible and sustainable model for land use and spatial development in urban and rural areas alike. This effort is expected to support current steps being pursued by the Federal Ministry of Environment, especially the Great Green Wall for the Sahara and Sahel Initiative (GGWSSI) in Northern Nigeria as contained in its 8 strategic pillars (Federal Government of Nigeria, 2012). It is therefore, most strategic that the Great Green Wall Initiative moves beyond or further from the fringes into protecting or creating regional or local corridors that will ensure ecological connectedness within and across the various regions in the nation, especially northern states; such that will localize the gains of the initiative.

Several studies have adopted the concept of ecological connectivity assessment for city-wide and regional scale developments. Mallarach and Marulli (2006) viewed the concept of ecological connectivity as related to the functional aspects of the actual connections among the different elements of the landscape, from energy to information and matter (such as nutrient cycles, pollen dispersion, and movements of flora or fauna populations or metapopulations), with a relatively high acceptance within the landscape ecology planning discipline. Results from several studies (Marulli \& Mallarach, 2005; Mallarach \& Marulli, 2006; Chang et al., 2012; Yigitcanlar \& Dizdaroglu, 2015) also indicate a strong correlation between infrastructure development and quality of natural environment (such as air, surface and ground water, soil and vegetation).

The specific context of this study is however based on the understanding and definition of 'green infrastructure' adopted from "The Green Infrastructure Working Group" under the leadership of "The Conservation Fund" and "USDA Forest Service" in the United States and put forward by Benedict and McMahon (2002) as: "a nation's natural life support system - an interconnected network of waterways, wetlands, woodlands, wildlife habitats, and other natural areas; greenways, parks and other conservation lands; working farms, ranches and forests; wilderness and other open spaces that support native species, maintain natural ecological processes, sustain air and water resources and contribute to the health and quality of life for communities and people". The study therefore seeks to make the case for concurrent development of the critically and equally valuable "green infrastructure" while seeking economic advancement through "built infrastructure" as this can further help build resilience to the realities of an increasing and changing climate, within an extensively altered ecosystem.

The use of remote sensing and Geographic Information System (GIS) tools generally have been found handy in spatial sciences as they provide a more objective, synoptic and continuous coverage of large areas, suitable for locating or for siting facilities \& utilities, even in very rugged and sensitive terrains, and understanding relationships that exists (Ozeair \& Mohesn, 2009; Suman, 2012; Chang, 2013; Du et al., 2014; Eneche et al., 2017). Thus, this study is hinged on the adoption of a GIS-based tool in modelling and mapping areas with high ecological potentials in Kaduna State (such as forest reserves, grazing areas, wetlands, etc.), such that will easily allow for green infrastructural development in the State, support inter-connectivity between such ecologically vibrant areas and mitigate the otherwise ravaging impacts associated with expansive infrastructure development at the scale being experienced and envisaged by Kaduna State Government between 2017 and 2050. 


\section{Methodology}

\subsection{Study Area}

Kaduna State lies between Latitudes $9^{\circ} 10^{\prime} \mathrm{N}$ and $11^{\circ} 40^{\prime} \mathrm{N}$ and Longitudes $6^{\circ} 02^{\prime} \mathrm{E}$ and $8^{\circ} 50^{\prime} \mathrm{E}$ covers an area of 44,408.3 sq.km. With about twenty-three (23) Local Government Areas (LGAs), the state is bordered to the South-West by Abuja - the Federal Capital Territory and Niger State, to the North-West by Katsina and Zamfara states, to the North-East by Kano and Bauchi states, and Plateau and Nasarawa states to the South-East (Figure 1).

Kaduna State experiences a tropical continental climate with distinct seasonal variation (Adejuwon, 1998). The climate varies from the northern to the southern part of the state with an annual mean temperature of between $24^{\circ} \mathrm{C}$ to $29^{\circ} \mathrm{C}$, the duration of rainfall varies between 150 days to 190 days with an annual rainfall incident ranging from $1,500 \mathrm{~mm}$ to $2,000 \mathrm{~mm}$, and relative humidity ranging between $20 \%$ and $30 \%$ in January, rising to between $60 \%$ and $80 \%$ in July. The hydrogeology and geomorphology of the study area is dominated by migmatite-gneiss complex (composed of granite-gnesis, biotite-gnesis and migmatite) and is found occurring in about 18 of the 23 Local Government Areas (LGAs) that comprise the State, spreading from the western parts of the state around Birnin-Gwari LGA to Jemma-Ikara LGA in the east. Part of this rock formation can also be found in the central and southern parts of Kaduna State specifically around Kajuru, Kaura and Lere LGAs. It is heavily present in the south-western part of the state, especially from around Kachia and Kagarko LGAs to the south east covering Sanga LGA. The second major rock formation in terms of prominence is the Pan-African Granodiorite, predominantly in the northern fringes of the state around Giwa LGA and western part of the Birnin-Gwari LGA, with pockets found around Chikun, Kachia and Kaura LGAs in central Kaduna, as well as in the south, around Jaba LGA. The Pan African Granodiorite is composed of Biotite and biotite horn-blended granodiorite, Coarse grained porphyritic, biotite hornblende granodiorite, Medium to coarse grained biotic granite (IBP Rural Water Supply Study, 2006).

The vegetation of the study area is transitional from the Guinea in the southern part to the Sudan Savannah in the Northern parts of the state (Nadbula et al., 2013). The vegetation in the southern part is characterized by scattered trees and woody shrubs. The trees have long taproots, thick barks and shed their leaves in dry season to survive the long dry season. In the northern part of the state grasses are common, with durable roots such that even when they dry up or are burnt during the dry season at the onset of rainfall they sprawl again. Some studies reveal that much of the original vegetation is now completely replaced with secondary type comprising largely of bushes and shrubs (Adejuwon, 1998; Al-Amin \& Dadan-Garba, 2014; etc.). However, there still exist pockets of (relatively) dense vegetation cover in the southern parts of the State than in the northern part and this variation is due to the amount of rainfall received in the area.

\subsection{Materials and Methods}

The study made use of remotely sensed data. Scenes of digital elevation model (DEM) covering Kaduna State were downloaded from the NASA website (https://earthexplorer.usgs.gov). The elevation dataset was downloaded and subsequently extracted based on the political boundary of the State and re-projected to the Universal Traverse Mercator (UTM Zone 32N) projection system. The elevation data downloaded contained little imperfections and/or holes which were however corrected by using the Fill algorithm before computing the slope for each pixel. Also, a comprehensive Land Use/Cover (LU/C) map of Kaduna State was obtained from Nigeria Infrastructure Advisory Facility (2017) and processed (Figure 2). The LU/C map (characterized by the use of twenty-four (24) LU/C categories) as well as the slope dataset of the state were then resampled to $50 \mathrm{~m}$ in order to enhance computational efficiency, given the spatial extent of the study area as well as to ensure data uniformity.

Furthermore, the slope and LU/C dataset were reclassified to a scale of 10, i.e. by logically assigning values to each pixel, say from $1-10$, based on the amount of effort (cost/barrier) that plants and animals may tend to thrive best and/or expend to move, respectively, in/from any one pixel to another. In other words, while an equal interval classification of slope was performed and reclassified accordingly, LU/C pixels were assigned values based on the researchers' judgement as shown in Table 1.

Also, the topographic dataset (elevation and slope) were reclassified, separately using same scale as shown in Table 1 (i.e. from 1 - 10). This is based on the fact that areas of high elevation and slope will make plants incur more effort to thrive and animals, more difficult to move. All the reclassified datasets were then fused to form one layer using the Multiple Criteria Evaluation (MCE) approach of weighted overlay. From the result of the weighted overlay, the cost distance raster was obtained, the cost path defined, and the final ecological connectivity path developed. In order to achieve all these computations and mapping, the model builder tool in 
ArcGIS 10.5 software was used to run the whole process - such that allowed flexibility and easy update of the results presented herein (See Figure 3).

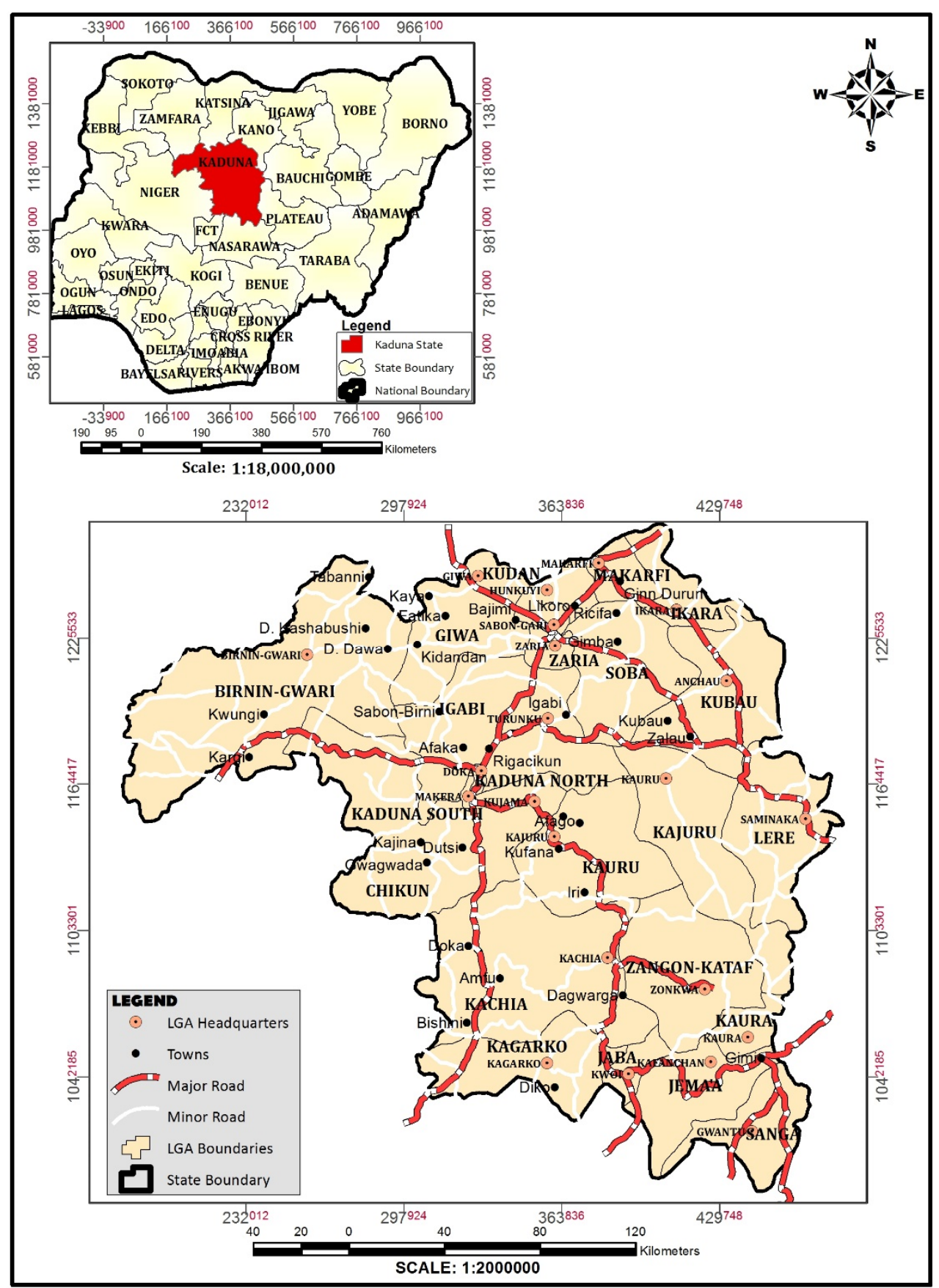

Figure 1. Nigeria showing Kaduna State, the study area 


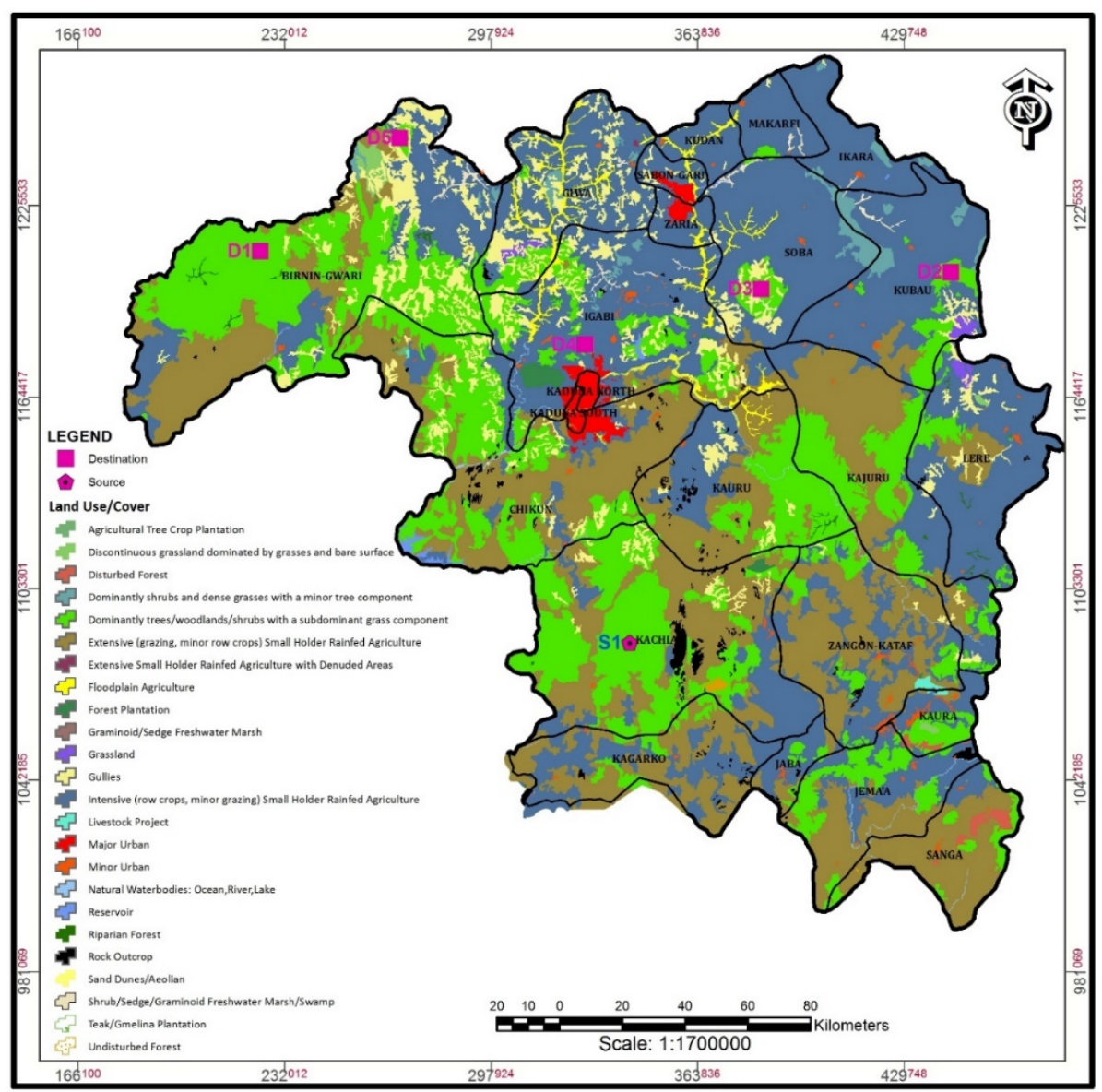

Figure 2. Land Use/Cover map of Kaduna State

Source: Nigeria Infrastructure Advisory Facility (2017).

Table 1. Ranking of LU/C Categories of Kaduna State

\begin{tabular}{lll}
\hline Feature Identifier & Comprehensive Land Use/Cover (LU/C) Categories & Assigned Value \\
\hline 1 & Gullies & 9 \\
2 & Reservoir & 3 \\
3 & Dominantly shrubs and dense grasses with a minor tree component & 2 \\
4 & Intensive (row crops, minor grazing) Small Holder Rainfed Agriculture & 5 \\
5 & Extensive (grazing, minor row crops) Small Holder Rainfed Agriculture & 4 \\
6 & Minor Urban & 8 \\
7 & Shrub/Sedge/Graminoid Freshwater Marsh/Swamp & 2 \\
8 & Floodplain Agriculture & 5 \\
9 & Rock Outcrop & 7 \\
10 & Dominantly trees/woodlands/shrubs with a subdominant grass component & 2 \\
11 & Natural Waterbodies: Ocean, River, Lake & 1 \\
12 & Extensive Small Holder Rainfed Agriculture with Denuded Areas & 6 \\
13 & Discontinuous grassland dominated by grasses and bare surface & 5 \\
14 & Major Urban & 10 \\
15 & Forest Plantation & 1 \\
16 & Riparian Forest & 1 \\
17 & Grassland & 2 \\
18 & Sand Dunes/Aeolian & 6 \\
19 & Graminoid/Sedge Freshwater Marsh & 4 \\
20 & Agricultural Tree Crop Plantation & 2 \\
21 & Livestock Project & 1 \\
22 & Disturbed Forest & 7 \\
23 & Undisturbed Forest & 1 \\
24 & Teak/Gmelina Plantation & 2 \\
\hline
\end{tabular}

Source: Authors' analysis (2017). 


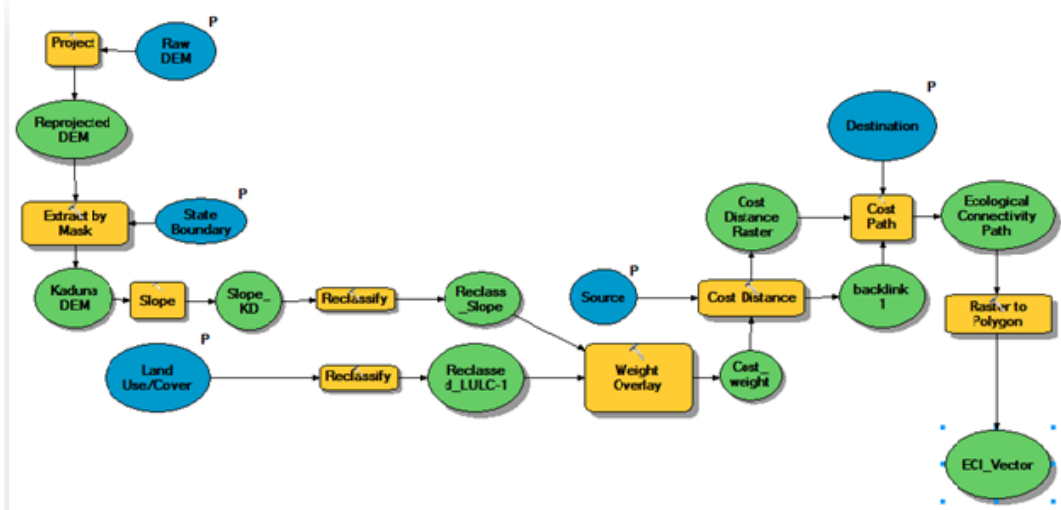

Figure 3. Flowchart of the model developed for the study

Source: Authors' GIS Analysis (2017).

\section{Results and Discussion}

The result of the topographic analyses (Figure $4 \mathrm{a}$ and $4 \mathrm{~b}$ ) are the processed Digital Elevation Model (DEM) and processed slope of the study area while Figure $5 \mathrm{a}$ and $5 \mathrm{~b}$ shows that of the slope as computed from the DEM data of the study area and a reclassified LU/C of the area. Kaduna State is shown to range from $242 \mathrm{~m}$ (above sea level, ASL) around Birnin-Gwari, Chikun and Sanga LGAs in the southwards and western areas of the State to about 1,324m (ASL) revealed around the hilly South-eastern parts of the State (Kaura, Zangon-Kataf, Lere and Kubau LGAs). Overall, the study area has an average altitude of $634.826 \mathrm{~m}$ (ASL). From the slope map (Figure $5 a)$, it was also clear that most of the LGAs noted for exhibiting either highland or lowland characteristics or both were areas found to have slopes of more than $50^{\circ}$. In addition to the LGAs listed above, Kachia, Jaba, Kajuru and Jema'a LGAs are also areas characterized with high slope values. Thus, as shown in Figure $4 \mathrm{~b}$ and Figure 5a), from the central part of the study area to the northern flank appears to be characterized by an almost uniform stretch of a relatively much lower highland coupled with relatively low slopes. Generally, the analysis of slope and LU/C reveal that most areas in the study area fall within the low slope classes (between $1-6$ ) while the reclassified LU/C map on the other hand shows the different classes based on the new reclassification scheme stated in the methodology (Table 1). Thus, the analysis show least cost areas that will support the development of a state-based green infrastructure. In other words, the higher the class, the more difficult or the more barrier there exist to impede the development of a sustainable ecological infrastructure.

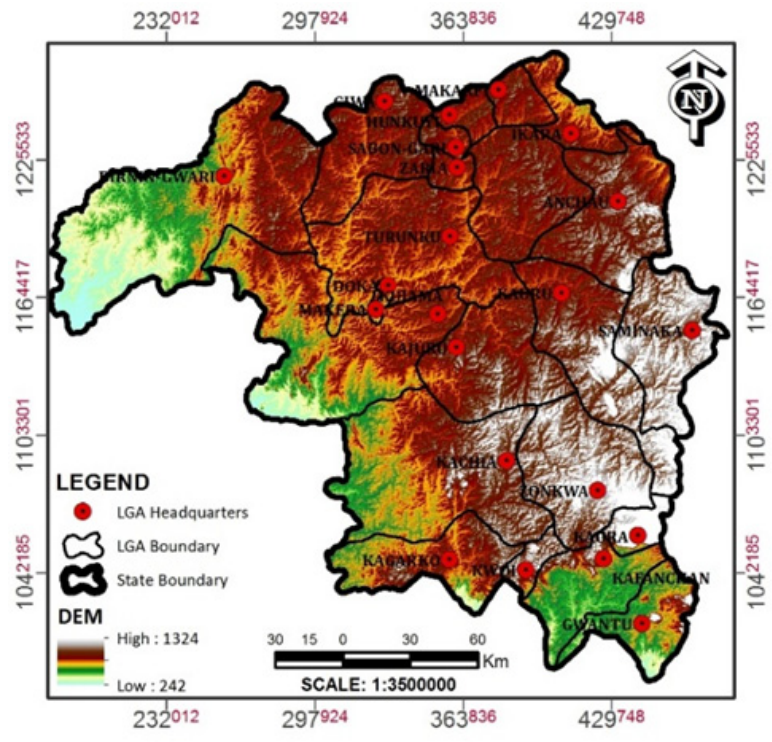

Figure 4a: DEM of Kaduna State

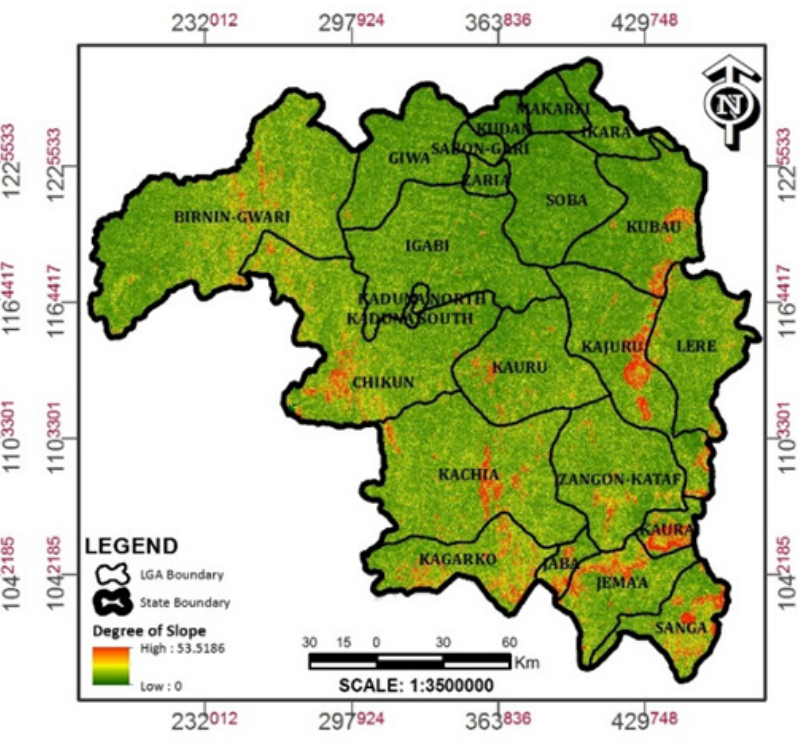

Figure 4b: Slope of Kaduna State

Source: Authors' GIS analysis (2017). 


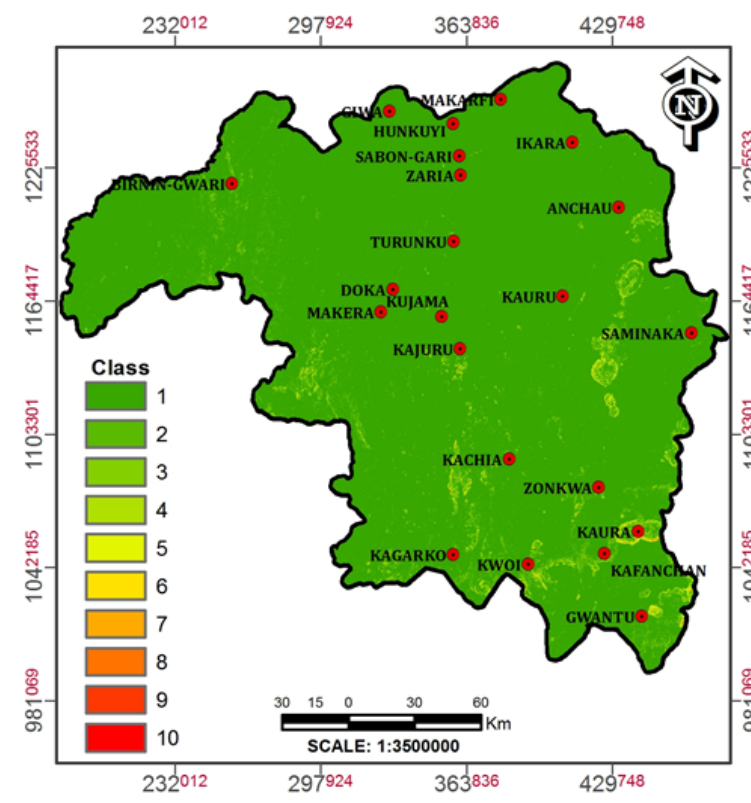

Figure 5a: Reclassified slope of Study area;

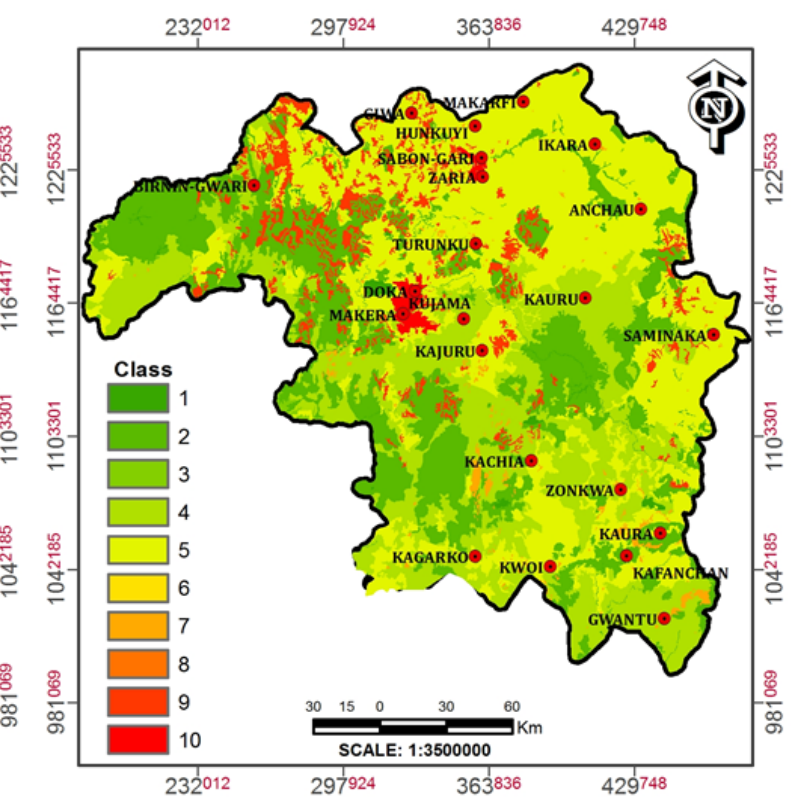

Figure 5b: Reclassified LU/C map of Study area

Source: Authors' GIS analysis (2017).

In order to establish a single framework, the maps from Figures $5 \mathrm{a}$ and $5 \mathrm{~b}$ were integrated using a weighted overlay analysis to reveal potential ecologically vibrant/connected areas in Kaduna State (Figure 6). The result of the weighted analysis as classified into five (5) categories from areas of high ecologically rated areas to areas with relatively no or negligible potential to allow for connectivity. Areas rated as high ecological zones are mostly areas of forest reserves, grazing reserves, etc. while areas of low to no connectivity were mostly urban (built-up) areas, areas of high slopes, rock outcrops, etc.

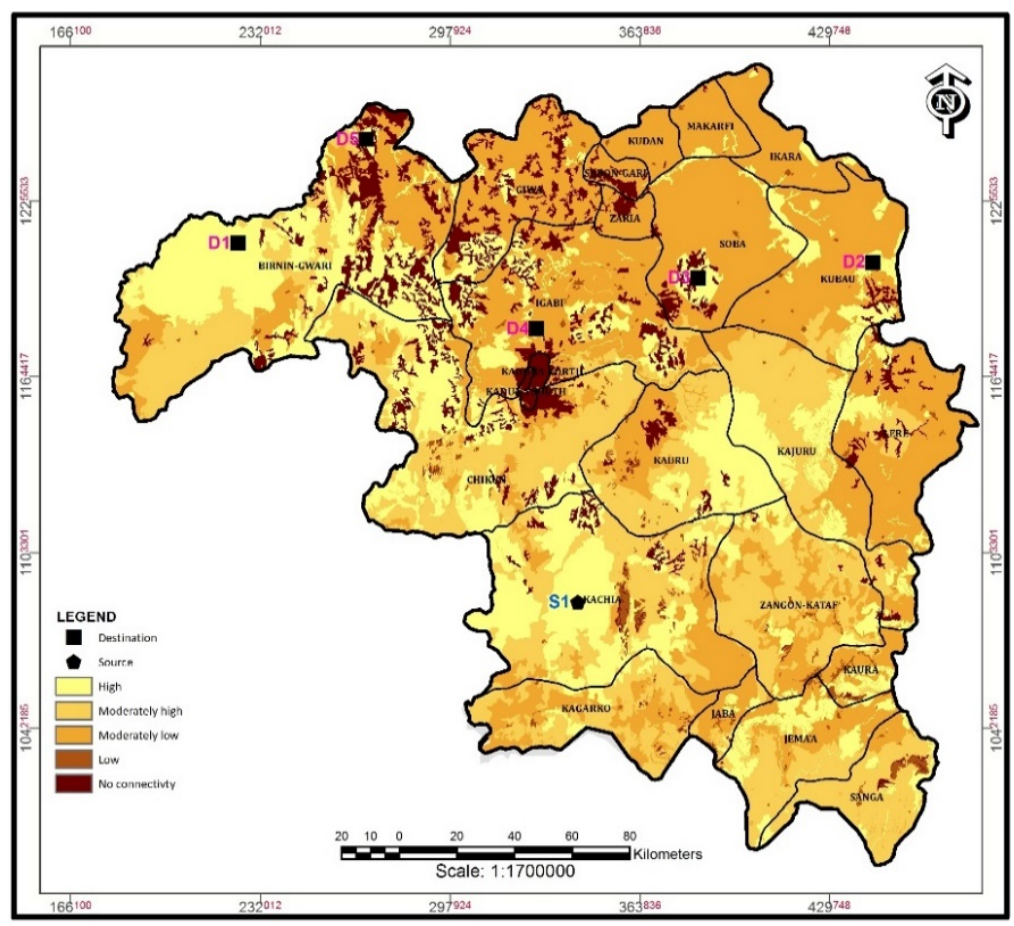

Figure 6. Potential ecologically vibrant areas of the Kaduna State

Source: Authors' GIS analysis (2017). 
The ecological connectivity approach of this study is based on a cost-distance model that aids in realizing areas of least cost connectivity between such discontinuous ecological areas. To this end, there was need to identify and locate sites to locate critical destination areas (D) towards the northern flank to some more settled source (S) region in the southern part of the State. This study (purposively) identified five (5) high ecologically rich areas within the study area (Figure 7) to form the base for green infrastructure investment (that compensates for the planned expansive built infrastructure). Although the Southern (source) point in Kachia LGA is currently a rich ecological resource, it may however face seasonal stress due to unplanned and unsustainable exploitation. The northern destination points face the threat of desert encroachment and drought. Hence, the need to establish and work towards ensuring ecological connectivity between the source area in the southern part as the main (and perhaps the only) area to enhance the ecological balance of the state.

Figure 7 shows the output raster in which each cell was assigned the cumulative cost to the closest source cell (in this case, $\mathrm{S}_{1}$ in Kachia LGA). Meanwhile, in utilizing the node/link cell representation used in graph theory, each center of a cell was considered a node and each node, connected to its adjacent nodes by multiple links. Every of such links had an impedance associated with it as derived from the weighted cost data associated with each cell as shown in Figure 7 and from the direction of movement through the cells. Hence, from the cost-distance map the varying cost-distances were computed per cell and classified as this formed an input in the computation of the least-cost path that was used to produce the path with least cost that could support and ensure ecological connectivity within the study area. In other words, the computation of the least-cost path tool was used to reveal the link with the most potential for which ecological corridors could be established; for which green belts could be constructed and sustained in the state. This ecologically vibrant linkage in the state is presented in Figure 8 .

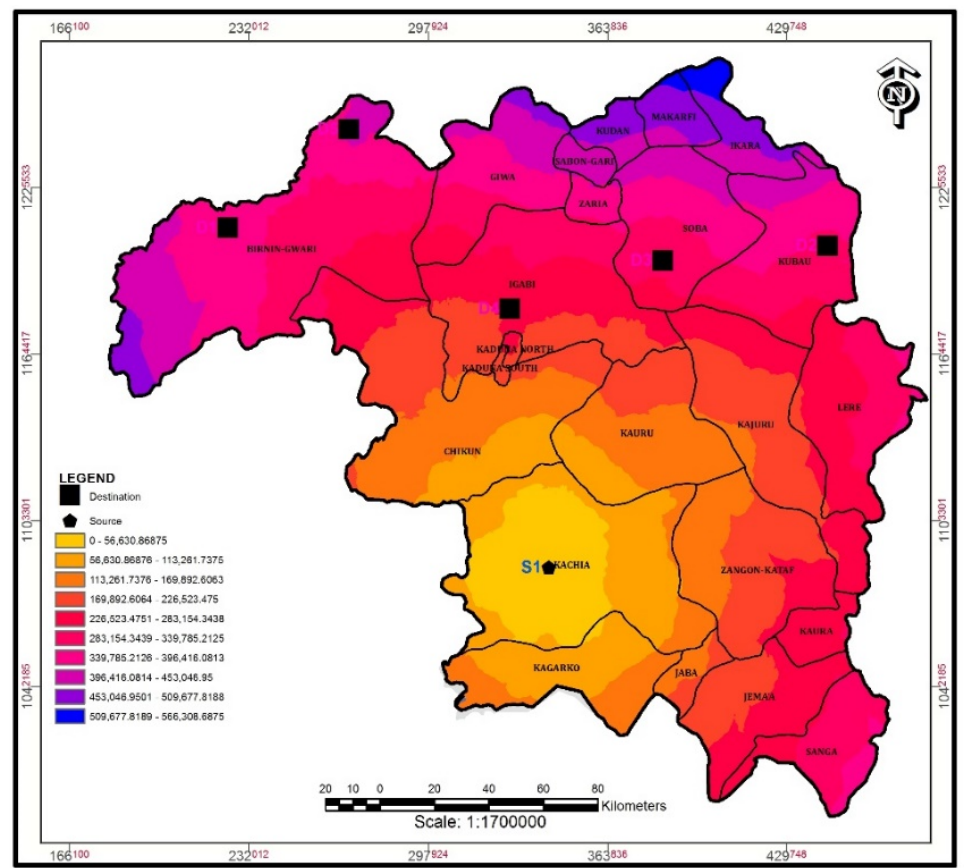

Figure 7. Cost-Distance map (from $\mathrm{S}_{1}-$ Kachia LGA, Kaduna State)

Source: Authors' GIS analysis (2017). 


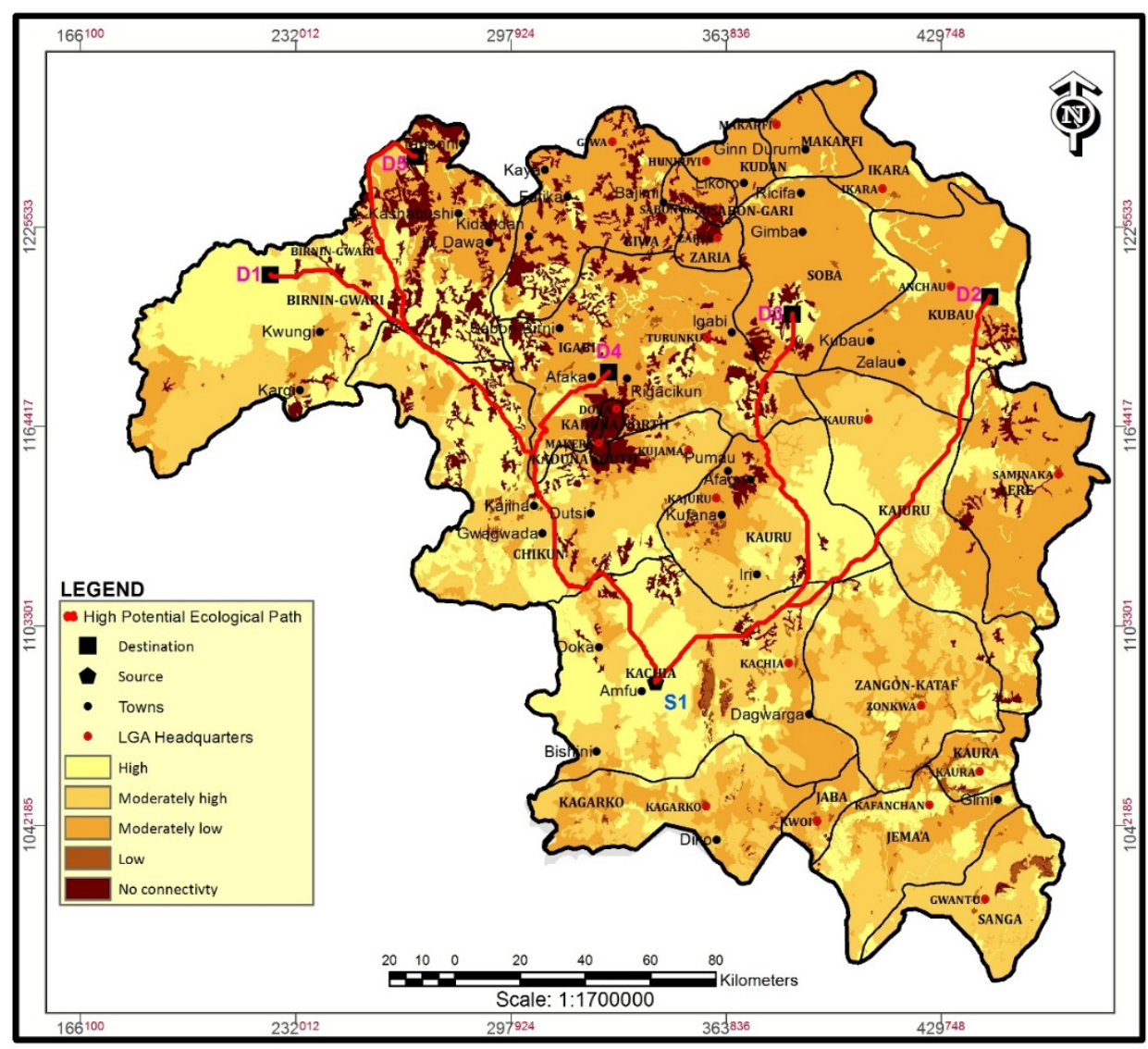

Figure 8. Ecological Connectivity Index (ECI) map of Kaduna State

Source: Authors' GIS analysis (2017).

The final ECI map as shown in Figure 8 above, reveals the path (or linking pixels) with the least-cost to support the investment and development of a (sustainable) green infrastructure network in Kaduna State. The ecological paths are such that traverses the areas where unfavourable spatial components such as rocks, hills, built-up areas, high slopes, etc. could compromise or serve as interference to either the growth and development of plants or the movement or safety of biodiversity along such corridors. Generally, the areas with higher ECI tend to be close or situated around/in forest reserves, riparian forest formations, etc. where ecological makeup are high. However, the best (least-cost) paths as shown in Figure 8 were computed and presented in Table 2.

Table 2. Summary of distances from source to destinations

\begin{tabular}{llll}
\hline Destination Point & Distance to Source $\mathbf{( K m )}$ & Percentage & Local Government Areas (LGAs) \\
\hline D1 & 198.031 & 22.555 & Birnin-Gwari, Chikun, Igabi \& Kachia \\
D2 & 171.364 & 19.518 & Kubau, Kauru, Kajuru \& Kachia \\
D3 & 149.443 & 17.021 & Soba, Igabi, Kauru \& Kachia \\
D4 & 131.039 & 14.925 & Igabi, Chikun \& Kachia \\
D5 & 228.119 & 25.982 & Birnin-Gwari, Chikun, Igabi \& Kachia \\
Total & 877.996 & 100 & \\
\hline
\end{tabular}

Source: Authors' GIS analysis (2017).

From Table 2 above, the longest ecological corridor (in this study) is from Birnin-Gwari to Kachia LGAs making up to 228.119 sq.km (26\%) on one axis and from Kubau to Kachia LGAs which is up to 171.364 sq.km $(20 \%)$ on the other axis. It is pertinent to note that the distances computed may be repeated in some cases but it tells the total distance that will be encountered if any of such links is to be invested in. In addition, these links can be as wide as possible and can also be implemented in piecemeal, just as the GGW as pointed out by (49). 
From a national perspective, it is particularly compelling to invest in Green Infrastructure as the Federal Government of Nigeria \& UN-REDD+ (2013) claimed to had lost more than 50\% of its forest cover since 1990 and currently less than $10 \%$ of the country is forested, with current deforestation rate estimated to be about $3.7 \%$ per year; one of the highest in the world. Therefore, there has to be smart moves to aid the recovery of agricultural and pastoral lands and help protect natural habitat too from grazing. Perhaps, the re-ignition of the true intents of grazing reserves and their actualization will go a long way so as not to compromise green investment programs such as the State-based Green Wall (SGW) presented invariably by the authors.

The implication of this study succinctly reveals also that not all LGAs in Kaduna State will be ecologically traversed but is well established in literature that such a strategy or a robust ECI would certainly create regional effect on the micro climate and subsequently, the ecology of all twenty three (23) LGAs of the State. Meanwhile, although Kaduna State does not fall within the Federal Government of Nigeria's GGWSSI, the study area is intrinsically linked (in ecological terms) to at least five (5) neighbouring States (Katsina, Kano, Zamfara, Jigawa and Bauchi) which are already earmarked in the Ecological Red List category of the GGWSSI framework. It may only be a matter of time before Kaduna State falls within the Red List category, especially if efforts are not set in motion to check the planned rapid infrastructure development across the state.

The impact of climate change, as expressed in the hazards that mostly plague the northern part of Nigeria: desertification and drought, requires an affirmative action, not just relying on the continentally driven framework of the GGWSSI but for such an approach to be domiciled at both state and national scales. Although, studies (Dalling \& Hubbel, 2002; United Nations Economic Commission for Africa, 2005; O'Connor \& Ford, 2014; etc.) tend to tilt in one direction and have in same vein pointed out the need for the review of GGWSSI, particularly as it relates to the use of trees, rather than shrubs or a mixture of both. These studies all point to the fact that planting trees (e.g. Acacia) mostly have slow growth speed and high local value as cooking fuel and more so, can be troublesome to groom especially in regions where illegal harvesting and poaching cannot be effectively halted. This may compromise the long-term success of the program and above all, the return on investment. In addition, it has been established in different studies that shrubs can produce micro-climate conditions that are up to $20^{\circ} \mathrm{C}$ cooler than the surrounding bare ground in arid areas with little cloud cover, thereby decreasing evapotranspiration, increase humidity and better growing conditions for grasses and sedges (Vetaas, 1992; D'Odorico, et al., 2010). However, care must be taken to ensure that the shrub species selected are (highly) drought-resistant as this can vary both temporally and by species.

\section{Conclusion and Recommendation}

This study further affirms the role of remote sensing and GIS in developing smart and objective policies which are capable of promoting sustainable ecological prosperity in the face of degrading ecosystem services and climate change, especially for countries striving to rapidly improve economic and living conditions. Areas with high ecological connectivity are revealed, such that if a state-wide program is to be embarked upon, the government can plan and deploy resources for necessary implementation.

Based on the findings of this study it is suggested that the Kaduna State government and other states, particularly in the northern fringes of the country ought to collaborate to develop phased programmes to objectively identify, effectively link and invest in green infrastructural development across ecologically vibrant areas in the state or the region, respectively. However, unlike the GGW project, this study throws more light on the use of drought-resistant shrubs alongside trees as they tend to reduce micro-climate, more significantly and also to define clearly grazing activities in the region.

Finally, other land surface descriptors (such as proximity to roads, soil properties, cultural setting of local communities, etc.) can be used to update and develop a more comprehensive ECI model for Kaduna State or as presented in this study, for the region. In addition, it is important to note that other (more abstract) variables such as customs, livelihoods, perception, insecurity, unplanned grazing, etc. of the local communities along paths linking ECI areas would become a major challenge to overcome by relevant government institutions. There is therefore, a social aspect of the study which would be required to conclude on a more robust ECI path model, most suitable by socio-economic and cultural definitions.

\section{Acknowledgement}

The authors are grateful to the UK DFID-funded programme, Nigeria Infrastructure Advisory Facility (NIAF) for some of the data used in this article. 


\section{References}

Adejuwon, S. A. (1998). An assessment of the pattern of rainfall fluctuations between 1922 and 1985 in Nigeria. An unpublished Ph.D Thesis, Department of Geography, Obafemi Awolowo University, Ile-Ife, Nigeria.

Africa Development Bank. (2014). An infrastructure action plan for Nigeria: Closing the infrastructure gap and accelerating economic transformation. African Development Bank Group.

Al-Amin, M., \& Dadan-Garba, A. (2014). Urban vegetation study of Kaduna Metropolis using GIS and remotely sensed data. Journal of Natural Sciences Research, 4(2), 160-171.

Benedict, M. A., \& McMahaon, E. T. (2012). Green infrastructure: smart conservation for the 21st century. Renewable Resources Journal, 22(4), 12-19.

Chang, K. T. (2013). Introduction of geographic information systems. United States: McGraw-Hill Education.

Collinge, S. K. (1996). Ecological consequences of habitat fragmentation: implications for landscape architecture and planning. Landscape and Urban Planning, 36(1), 59-77.

Dalling, J. W., \& Hubbell, S. P. (2002). Seed size, growth rate and gap microsite conditions as determinants of recruitment success for pioneer species. Journal of Ecology, 90(1), 557-568.

D'Odorico, P., Fuentes, J. D., Pockman, W. T., Collins, S. L., He, Y., Medeiros, J. S., . . Litvak, M. E. (2010). Positive feedback between microclimate and shrub encroachment in the northern Chihuahuan desert. Ecosphere, 1, Article 17.

Du, P., Liu, P., Xia, J., Feng, L., Liu, S., Tan, K., \& Cheng, L. (2014). Remote sensing image interpretation for urban environment analysis: Methods, system and examples. Remote Sensing, 6(10), 9458-9474. doi: $10.3390 /$ rs6109458

Eneche, P. S., Nwosu, E. E., \& Abu, H. O. (2017). Geospatial analysis of the impact of urban built-up development on the distribution of suitable solid waste dumpsite in Ile-Ife, Nigeria. American Journal of Environmental Engineering, 7(4), 82-92. https://doi.org/10.5923/j.ajee.20170704.02

Federal Government of Nigeria \& UN-REDD+. (2013). Readiness Preparation Proposal. Forest Carbon Partnership Facility (FCPF) and The United Nations Collaborative Programme on Reducing Emissions from Deforestation and Forest Degradation in Developing Countries (UN-REDD+).

Federal Government of Nigeria. (2012). Great Green Wall for the Sahara and Sahel Initiative: National Strategic Action Plan. Federal Ministry of Environment, Nigeria.

Ifatimehin, O. O., Eneche, P. S., \& Negedu, C. E. (2016). Assessment of the influences of bioclimatic variables on the incidence of hyperthermia diseases in Ilorin Metropolis. Nigerian Journal of Tropical Geography, $7(2), 1106-1119$.

Intergovernmental Panael on Climate Change. (2014). Climate Change 2014: Impacts, Adaptation, and Vulnerability. Cambridge, UK: Cambridge University Press.

Mallarach, J., \& Marull, J. (2006). Impact assessment of ecological connectivity at the regional level: recent developments in the Barcelona Metropolitan Area. Impact Assessment and Project Appraisal, 24(2), 127-137.

Marulli, J., \& Mallarach, J. (2005). A GIS methodology for assessing ecological connectivity: application to the Barcelona Metropolitan Area. Landscape and Urban Planning, 71(1), 243-262.

Musa, S., Onwuka, S. U., \& Eneche, P. S. (2017). Geospatial analysis of land use/cover dynamics in Awka Metropolis, Nigeria: A sub-pixel approach. Journal of Geography, Environment and Earth Science International, 11(4), 1-19. https://doi.org/10.9734/JGEESI/2017/35209

National Planning Commission. (2015). National Integrated Infrastructure Master Plan. The Presidency, Abuja, Nigeria.

Ndabula, C., Averik, P., Jidauna, G., Abaje, I., Oyatayo, T., \& Iguisi, E. (2013). Analysis of the spatio-temporal dynamics of landuse/ landcover stuctures in the Kaduna innercore city region, Nigeria. American J. Env. Protection, 1(4), 112-119.

Nigeria Infrastructure Advisory Facility. (2017). Kaduna State Infrastructure Master Plan. London, UK: Adam Smith International and the Department for International Development (DFID). 
O'Connor, D., \& Ford, J. (2014). Increasing the effectiveness of the "Great Green Wall" as an adaptation to the effects of climate change and desertification in the Sahel. Sustainability, 6(1), 7142-7154. doi:10.3390/sub6107142

Onwuka, S. U., Eneche, P. S., \& Ismail, N. A. (2017). Geospatial modeling and prediction of land use/cover dynamics in Onitsha Metropolis, Nigeria: A sub-pixel approach. British Journal of Applied Science and Technology, 22(6), 1-18. https://doi.org/10.9734/CJAST/2017/35294

Suman, P. (2012). Location allocation for urban waste disposal site using multi-criteria analysis: A study on Nabadwip Municipality, West Bengal, India. International Journal of Geomatics and Geosciences, 3(1), 74-88.

United Nations Economic Commission for Africa. (2005). Africa's Regional Review: Report on Energy. Addis Ababa, Ethiopia: United Nations Economic Commission for Africa.

Vetaas, O. R. (1992). Micro-site effects of trees and shrubs in dry savannas. Journal of Vegetatal Science, 3, 337-344.

World Bank. (2010). World Development Report - Development and Climate Change. Washington, DC, USA: The World Bank.

World Bank Group . (2015). Highways to Success or Byways to Waste: Estimating the Economic Benefits of Roads in Africa. World Bank Group, Washington.

Yigitcanlar, T., \& Dizdaroglu, D. (2015). Ecological approaches in planning for sustainable cities: A review of the literature. Global Journal of Environmental Science \& Management, 1(2), 159-188.

Yigitcanlar, T., \& Lee, S. (2014). Korean ubiquitous-eco-city: a smart-sustainable urban form or a branding hoax? Tech. Forecasting Soc. Change, 89(1), 100-114.

\section{Copyrights}

Copyright for this article is retained by the author(s), with first publication rights granted to the journal.

This is an open-access article distributed under the terms and conditions of the Creative Commons Attribution license (http://creativecommons.org/licenses/by/4.0/). 